\title{
A Comparative Thermal Analysis of Fire-off Treated Cotton, PET and Co/PET Fabrics
}

\author{
Raziye Atakan, Gülay Özcan \\ Istanbul Technical University, Faculty of Textile Technologies and Design, Inonu Cad. No: 65 34437, Gumusuyu, Istanbul
}

Corresponding Author: Raziye Atakan, ratakan@itu.edu.tr

\begin{abstract}
The present paper investigates the capability of MCC and TGA methods by testing the thermal performance of commercially available flame-retardant chemical called Fire-off on polyethylene terephthalate (PET) and cotton (Co) fabrics and their corresponding blends (Co/PET). Fire-off was applied to the fabric through impregnation method and the resulting properties of these fabrics were assessed in terms of combustion behavior by use of micro combustion calorimeter (MCC) and thermogravimetric analysis (TGA). TGA results revealed that Fire-off could greatly enhance char residues of cotton, PET and Co/PET fabrics at high temperature region. MCC results indicated that Fire-off treatment could significantly decrease the heat release capacity (HRC), heat release rate (HRR), total heat release rate (THR) and peak heat release rate (pHRR) of cotton, PET and Co/PET fabrics. According to comparison results, a near-perfect agreement between MCC and TGA data were found in terms of degradation temperatures and mass loss rates of fabric samples
\end{abstract}

\author{
ARTICLE HISTORY \\ Received: 02.07.2019 \\ Accepted: 11.10.2019

\section{KEYWORDS} \\ micro-scale combustion \\ calorimeter, thermogravimetric \\ analysis, thermal \\ characterization tests, cotton, \\ PET, Co/PET fabrics.
}

\section{INTRODUCTION}

With the development of science and technology and the improvement of people's living standard, the textile products show diversity in terms of application areas from the medical, military, home textiles to the common apparels. However, most of the textile products are composed of $\mathrm{C}, \mathrm{H}, \mathrm{O}$, which are flammable and ignitable [1]. Especially, as we all know that the beddings and interior decoration of curtains with feature of flammability and ignitibility are the most of the fire hazard products worldwide [2]. Therefore, manufacturers are enforced by strict standards to look for new solutions [3]. Currently, it is evidently clear that flammable textile materials need to be tested by various independent thermal testing methods to assess the effectiveness of the FR formulations properly [4].

As a new and convenient thermal analysis technique for characterizing flammability properties of combustible materials developed in the early 2000's by the U.S.
Department of Transportation Federal Aviation Administration, the micro combustion calorimeter (MCC) test is a small-scale flammability testing method based on the principle of oxygen consumption [5-7]. The test is conducted in a laboratory environment in which milligramscale specimen are heated at a controlled rate in an oxidizing atmosphere to achieve total material decomposition. Heat release rates associated with the combustion are then calculated by means of oxygen consumption. The temperatures over which combustion heat is released are also measured.

It serves as an alternative analytical test to verify material combustion consistency in end product. It is usually conducted in conjunction with the typical analytical tests such as fourier transform infrared spectrophotometer (FTIR), thermogravimetric analysis (TGA) or differential scanning calorimetry (DSC) used to validate formulation consistency in the most of research articles to achieve comprehensive evaluation of all kind of materials such as

To cite this article: Atakan R, Özcan G, 2019. A Comparative Thermal Analysis of Fire-off Treated Cotton, PET and Co/PET Fabrics. Tekstil ve Konfeksiyon 29(4), 311-316. 
polymers, fillers, composites, fabrics, nanocomposites etc. $[2,3,8-23]$.

It offers some benefits over other thermal tests of textile materials such as providing a quantitative comparison of combustion characteristics of textile materials such as peak heat release rate, the most significant parameter related to fire hazard of textile materials. This analysis is more difficult using cone calorimeter because of low thickness of textile fabrics [24]. Because, the experimental results of cone calorimeter are highly depended on the sample material thickness, ignition sources, orientations, ventilation and edge conditions. The cone calorimeter test requires repeated sampling of larger specimens (e.g., 10x $10 \mathrm{~cm})$. Textile fabrics as thermally thin samples show larger heat release rate (HRR) values than thick samples. MCC test also provides quantitative information to correlate flammability behavior of new formulations during product development. It uses a fast cycle-time to obtain results in minutes [25], and it is capable of differentiating small differences amongst samples, which show similar flammability. In addition, fire growth index (FGI) of fabric samples can be calculated from the thermal combustion parameters measured by MCC in order to assess their burning hazard potentials. [26].

In the area of flame retardancy of textiles, the phosphorous based Flame Retardants (FRs) demonstrate lower toxicity profiles than the halogen-based compounds [27,28]. There have been ongoing attempts on synthesis and application of P-N containing eco-friendly FR systems, which are also more sustainable [1,29-31] For instance, in a current study [32], P-N-Si synergistic flame retardant was synthesized with combining cyclodiphosphazane derivatives with silicon-containing compounds and applied to cotton fabrics. Effective FR properties were achieved with increased LOI values (from 18.2 to 52.9) and decreased total heat release (THR) and effective heat combustion (EHC) values. In another innovative study [33], casein-based, $\mathrm{P}-\mathrm{N}$ containing FRs with $-\mathrm{COO}^{-} \mathrm{NH}_{4}^{+}$and $-\mathrm{P}=\mathrm{O}\left(\mathrm{O}^{-} \mathrm{NH}_{4}{ }^{+}\right)_{2}$ reactive groups, were synthesized based on a casein hydrolysis solution for cotton fabrics. Cotton fabrics, after the treatment, exhibited highly efficient flame retardancy by achieving $39.5 \%$ LOI value. The study also showed that the biomacromolecules can be flame retardant alternatives for textiles to synthetic chemicals as an environmentally friendly approach.

In our previous study [34], P-N synergetic FR agent (PVP (PR)-P-DCDA) was synthesized using polyvinyl alcohol, phosphoric acid, hydrophilic PET resin (PR), and dicyandiamide (DCDA). FR treated cotton, PET and Co/PET fabrics demonstrated no ignition with LOI values of $+26 \% .100 \%$ PET fabric showed increased LOI values (from $22.5 \%$ to $33 \%$ ) at very low add-ons (8-9\%). In addition, investigation of mechanical properties of this FR, called Fire-off, treated fabrics exhibited an increase in abrasion, pilling, strength and elongation properties [35].
In this study, thermal properties and flame retardancy of Fire-off treated cotton, PET and Co/PET fabric samples were characterized by TGA and MCC in order to complete all thermal behaviors and product assessment of Fire-off. The capability of MCC and TGA was compared for analyzing FR performance of samples. In addition, FGI values of treated various samples were calculated using the combustion parameters of MCC in order to detect their fire risks.

\section{MATERIAL AND METHOD}

\subsection{Material}

Scoured $100 \%$ cotton (plain weave, $133 \mathrm{~g} / \mathrm{m}^{2}$ ), $100 \%$ PET (plain weave, $172 \mathrm{~g} / \mathrm{m}^{2}$ ) and 50/50\% Co/PET fabrics (plain weave, $120 \mathrm{~g} / \mathrm{m}^{2}$ ), which represent apparel and home textile fabrics were supplied from Zorlu Mensucat/ Turkey for experiments. P-N synergetic FR chemical Fire-off was supplied from Eksoy Chemical/Turkey.

\subsection{Fabric Treatment Process}

Each new section and subsection should have a heading consisting of an Arabic numeral followed by a period. Please a single space before and after the section title (see this template). Scoured fabrics were padded in Fire-off (400 $\mathrm{g} / \mathrm{L})$ solutions in three dips and nips using a two-roll laboratory padder (ATAÇ F-350 model) at room temperature, and squeezed to a wet pick-up of $85 \pm 2 \%$. The padded fabrics were dried at $100^{\circ} \mathrm{C}$ for $3 \mathrm{~min}$ in an oven (ATAÇ EV 250 model) and subsequently cured using a mini ram (ATAÇ GK 40 model) at $180^{\circ} \mathrm{C}$ for $3 \mathrm{~min}$. The add-on values of cotton, PET and Co/PET fabrics were obtained as $21-22 \%, 16-17 \%$ and $19-20 \%$.

\subsection{Thermal Characterization Tests}

Thermogravimetric measurements were run on SEIKO Exstar 6200 TG/DTA instrument under a dry nitrogen atmosphere (purging rate $20 \mathrm{~mL} / \mathrm{min}$ ) and $10^{\circ} \mathrm{C} / \mathrm{min}$ heating rate from 30 to $800^{\circ} \mathrm{C}$ using $4-5 \mathrm{mg}$ sample amounts in open platinum pans.

The combustion performance of samples was measured by a MCC instrument (MCC, Turkey) equipped with a 40/L alumina pan in accordance with ASTM D7309, Method A. The samples $(\sim 5 \mathrm{mg})$ were first heated from room temperature to $750^{\circ} \mathrm{C}$ in an $80 \mathrm{~cm}^{3} / \mathrm{min}$ nitrogen stream with at a linear heating rate of $1^{\circ} \mathrm{C}$. Then the thermal degradation products of the sample in nitrogen were mixed with a $20 \mathrm{~cm} 3 / \mathrm{min}$ oxygen stream flow and combustion in a furnace at $900^{\circ} \mathrm{C}$ for $10 \mathrm{~s}$. The heat of combustion of the pyrolysis products were measured by oxygen consumption principle. Each sample was run in three replicates and the averages of MCC parameters were calculated from the three measurements. The key fire parameters including heat release rate (HRR), total heat release (THR in $\mathrm{kJ} / \mathrm{g}$ ), heat release capacity (HRC in $\mathrm{J} / \mathrm{g} \mathrm{K}$ ), peak heat release rate ( $\mathrm{pHRR}$ in $\mathrm{W} / \mathrm{g}$ ) and temperature at maximum heat release rate (Tmax) were measured. The mass of specimen 
remaining after the test was also measured to evaluate char yield. The fire growth index (FGI) was also calculated using the ratio of pHRR of the material and Tmax (FGI=pHRR/ Tmax). The bigger the value of FGI, the greater the fire hazard.

\section{RESULTS AND DISCUSSION}

TGA is the most used method to rapidly evaluate the thermal stability of different materials, composites etc. It also exhibits the decomposition of polymers at various temperatures.

\section{$100 \%$ Cotton}

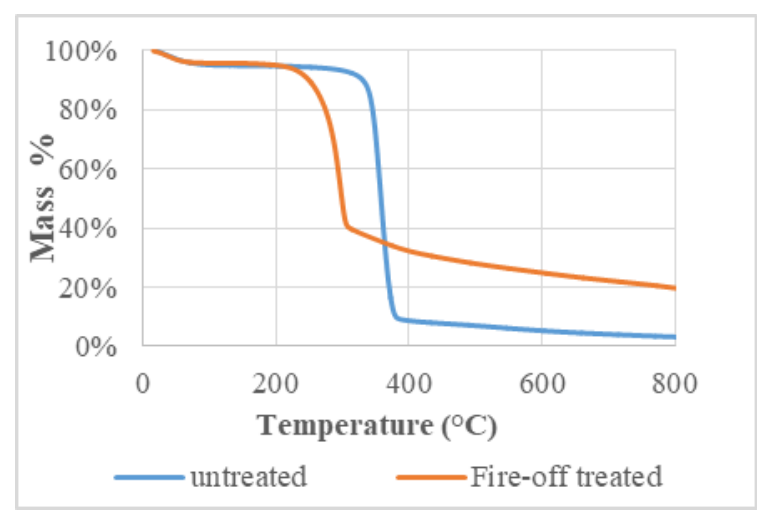

\section{0\% PET}

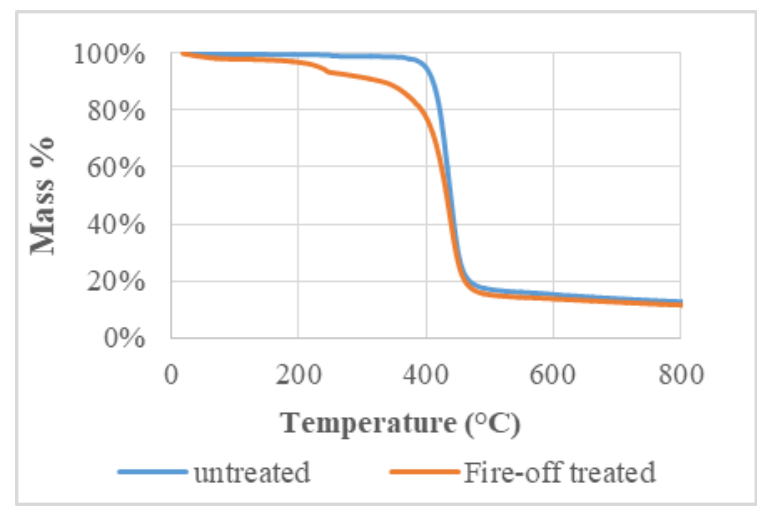

\section{$50 / 50 \% \mathrm{Co} / \mathrm{PET}$}

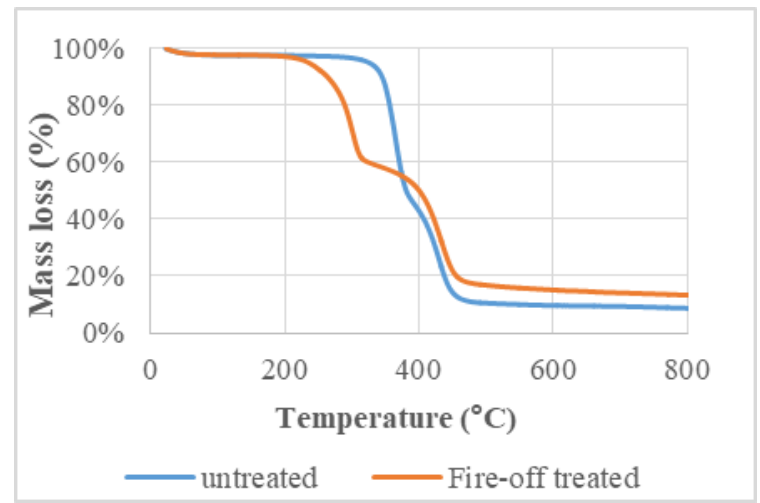

The thermal degradation and decomposition processes of untreated and treated fabrics were monitored by TGA. Subsequently, TGA measurement was compared with the MCC test in order to confirm the catalytic charring effect of the Fire-off treatments on cotton, PET and Co/PET fabrics. Both TG and MCC curves of untreated and treated samples are depicted in Figure 1, and the corresponding data of TGA and MCC are listed in Table 1 and 2, respectively.
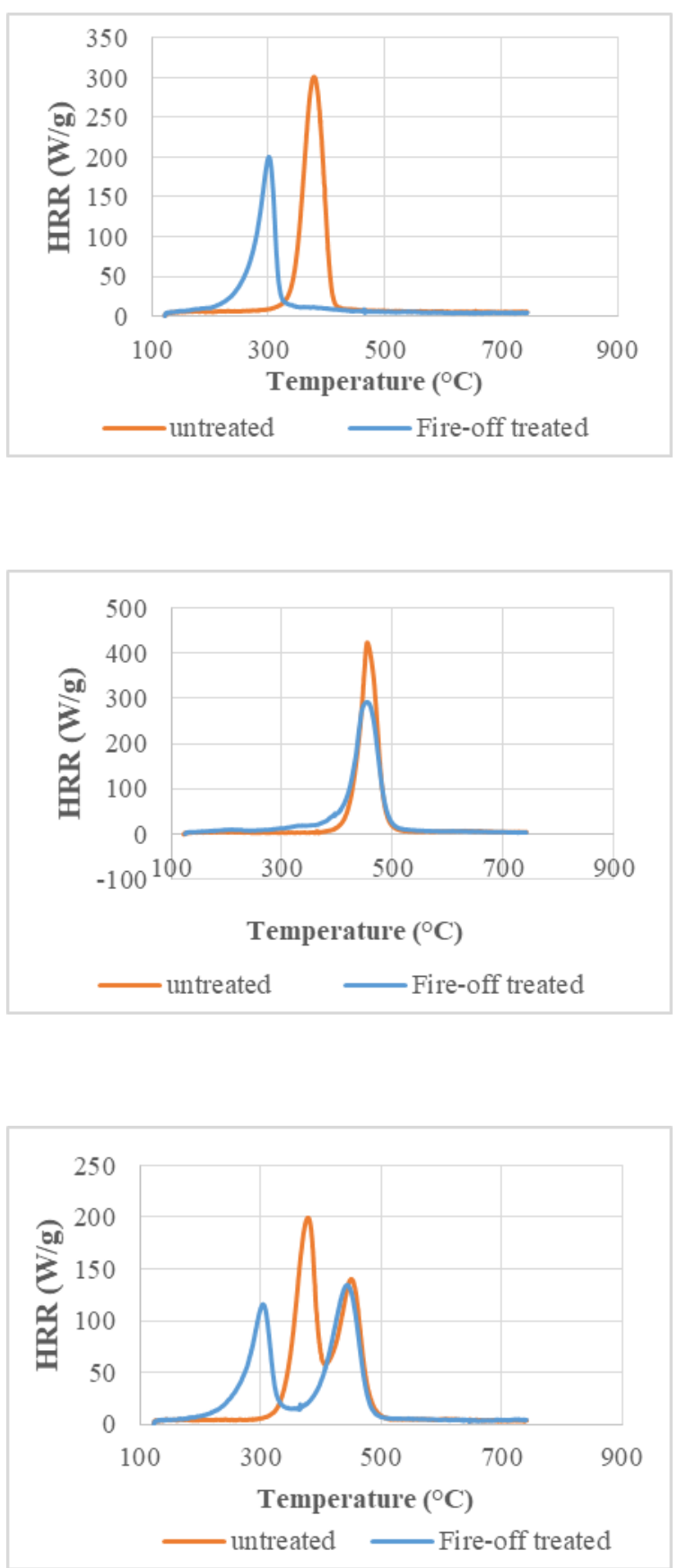

Figure 1. TG and HRR curves of untreated and treated fabrics. 
Table 1. TGA data of untreated and treated fabrics.

\begin{tabular}{cccc}
\hline Fabric Type & $\boldsymbol{T}_{1}{ }^{*}\left({ }^{\circ} \mathbf{C}\right)$ & $\boldsymbol{T}_{2} *\left({ }^{\circ} \mathbf{C}\right)$ & Residue at $\mathbf{7 5 0} \mathbf{C}^{\circ}(\mathbf{\%})$ \\
\hline 100\% Cotton & 342 & 373 & 3.6 \\
100\% Cotton- treated & 273 & 310 & 21.04 \\
100\% PET & 414 & 455 & 13.12 \\
100\% PET - treated & 406 & 456 & 11.92 \\
50/50\% CO/PET & $345-381$ & $403-450$ & 9.01 \\
50/50\% CO/PET- treated & $272-311$ & $395-456$ & 13.69 \\
\hline
\end{tabular}

Table 2. MCC data of untreated and treated fabrics.

\begin{tabular}{|c|c|c|c|c|c|c|c|}
\hline Fabric Type & $\begin{array}{c}\text { HR Capacity } \\
(\mathrm{J} / \mathrm{g} \mathrm{K})\end{array}$ & $\begin{array}{c}\text { pHRR } \\
(W / g)\end{array}$ & $\mathbf{T}_{\max }\left({ }^{\circ} \mathrm{C}\right)$ & $\begin{array}{r}\text { THR } \\
(\mathbf{k J} / \mathrm{g})\end{array}$ & $\begin{array}{c}\text { Mass Loss at } \\
750^{\circ} \mathrm{C}(\%)\end{array}$ & $\begin{array}{l}\text { Residue at } \\
750^{\circ} \mathrm{C}(\%)\end{array}$ & FGI \\
\hline $100 \%$ Cotton & 315.33 & 287.4 & 377.6 & 14.57 & 94.94 & 5.06 & 0.76 \\
\hline $100 \%$ Cotton-treated & 221.33 & 201.97 & 303.03 & 10.37 & 79.74 & 20.26 & 0.66 \\
\hline $100 \%$ PET & 465.67 & 426.67 & 455.27 & 18.37 & 87.86 & 12.14 & 0.93 \\
\hline $100 \%$ PET -treated & 333.33 & 305.13 & 451.93 & 19.2 & 90.45 & 9.55 & 0.67 \\
\hline $50 / 50 \% \mathrm{Co} / \mathrm{PET}$ & 219 & $202.03-$ & $377.73-$ & 16.57 & 91.48 & 8.52 & 0.53 \\
\hline $50 / 50 \% \mathrm{Co} / \mathrm{PET}$-treated & 143.67 & 132.93- & $442.23-$ & 15.1 & 87.86 & 12.14 & 0.30 \\
\hline
\end{tabular}

Phosphorous and nitrogen (P-N) containing FR systems can form a cross-linked network within the cellulose. Hence, they inhibit the release of volatile combustible fragments and enhance the formation of char. These systems are able to reduce cellulose inflammability by the mechanisms of dehydration, phosphorylation, and phosphate- ester decomposition. Generally, FR agents is supposed to decompose before the decomposition temperature of the textile substrates to interfere with the burning process [36,37].

As shown from TG curves in Figure 1, cotton begins to break down at $342{ }^{\circ} \mathrm{C}\left(T_{1}\right)$ and performs a one-step thermal degradation behavior because of the glycosyl units to char. The degradation is maximum at around $373^{\circ} \mathrm{C}\left(T_{2}\right)$. Cellulose degradation involves the decomposition of the glycosyl units to an aliphatic char at lower temperatures and the depolymerisation of such units to volatile products containing levoglucosan at higher temperature [34,38]. Fire-off treatment leads to a strong reduction of the cellulose decomposition temperature, which is indicated by the initial decomposition $\left(T_{1}\right)$ value $\left(342\right.$ to $\left.273^{\circ} \mathrm{C}\right)$ for treated sample. While the char residue of untreated cotton was $3.60 \%$, around $21 \%$ char residue at $750^{\circ} \mathrm{C}$ was measured by TGA for treated cotton, which indicates high thermal stability due to the interaction of cellulose and Fireoff during combustion. This trend prevents cotton fabrics to further degradation. In parallel to TG curves, as clearly seen from HRR curves in Figure 1, cotton fabric goes through a one-step pyrolysis process due to the glycosyl units to char. The degradation of untreated cotton is maximum at $377^{\circ} \mathrm{C}$ $\left(T_{\max }\right)$ and it presents the peak heat release rate $(\mathrm{pHRR})$ of $287.4 \mathrm{~W} / \mathrm{g}$. On the other hand, degradation of treated cotton starts earlier, is maximum at around $303{ }^{\circ} \mathrm{C}\left(T_{\max }\right)$, representing a lower $\mathrm{pHRR}$ value $(201 \mathrm{~W} / \mathrm{g})$. The residue (\%) obtained by MCC is 5.06, which is very close the one of TGA (3.6).

TG curve of untreated PET can be suitably fitted by a single stage reaction in nitrogen similar to cotton fabric. According to TGA data in Table 1, treated PET fabrics, demonstrated a slight decrease in maximum decomposition temperature $\left(414\right.$ to $\left.406^{\circ} \mathrm{C}\right)$. The char residue at $750^{\circ} \mathrm{C}$ were the approximately same percentage (13 to $\sim 12 \%)$ for untreated and treated samples. MCC data confirms that the thermal decomposition started at around $375^{\circ} \mathrm{C}$ for the untreated PET fabric. The decomposition intensified as the temperature was increased, as indicated by rising HRR. It reached to maximum at $455^{\circ} \mathrm{C}$ with the $\mathrm{HRR}$ at $426 \mathrm{~W} / \mathrm{g}$ (pHRR). The decomposition ended at $518^{\circ} \mathrm{C}$, the char residue was measured as $12.14 \%$ at $750^{\circ} \mathrm{C}$. On the other hand, some significant changes in the MCC parameters were observed after Fire-off treatment of on PET fabrics. For instance, the initial decomposition temperature was decreased to $300^{\circ} \mathrm{C}$ and a lowered pHRR of $305 \mathrm{~W} / \mathrm{g}$ was obtained at $451^{\circ} \mathrm{C}\left(T_{\max }\right)$. The decomposition ended at $518^{\circ} \mathrm{C}$ same as the untreated one. The char residues were calculated around $12 \%$ and $\% 10$ for untreated and treated samples, respectively.

In case of Co/PET fabrics, as seen in TG curves, the pyrolysis proceeds in two independent steps, which exhibit a thermal degradation typical of a polymer blend: the former was attributable to cotton $\left(345^{\circ} \mathrm{C}\right.$ for untreated, $272^{\circ} \mathrm{C}$ for treated fabrics) and the latter to PET $\left(403^{\circ} \mathrm{C}\right.$ for untreated, $395^{\circ} \mathrm{C}$ for treated fabrics). The char residue at $750^{\circ} \mathrm{C}$ leads an increase from approximately $9 \%$ to $13 \%$ 
for treated $\mathrm{Co} / \mathrm{PET}$. HRR curves for Co/PET fabrics versus temperature exhibit two major degradation steps as same as the TG curves of $\mathrm{Co} / \mathrm{PET}$. For untreated $\mathrm{Co} / \mathrm{PET}$, the first peak $\left(\mathrm{HRR}_{1}\right)$ is around $193 \mathrm{~W} / \mathrm{g}$ and the second peak $\left(\mathrm{HRR}_{2}\right)$ is around $132 \mathrm{~W} / \mathrm{g}$. Fire-off treatment demonstrate higher effectiveness in decreasing heat release rate after $\mathrm{HRR}_{1}$ (from 193 to $120 \mathrm{~W} / \mathrm{g}$ ) than $\mathrm{HRR}_{2}$ (from 132 to 130 $\mathrm{W} / \mathrm{g}$ ). It is obviously seen that $\mathrm{Co} / \mathrm{PET}$ fabrics start degradation process earlier after FR treatments, at around $305^{\circ} \mathrm{C}$, whereas untreated sample starts to degrade at around $380^{\circ} \mathrm{C}$.

Additionally, as seen in Table 2, some other prominent changes in the MCC parameters were observed when all fabric types were treated with Fire-off. A strong reduction in HRC and THR was obtained for treated samples. Decreased THR values, which refer to the total available energy in the material in a fire situation, which suggest that more volatile products are catalytically carbonized to participate in the charring process, rather than transfer into the MCC combustor.

When compared FGI values of all fabrics, it should be noted that untreated PET fabric has the most burning hazard potential with the highest FGI value of 0.93 , cotton fabric has 0.76 value and $\mathrm{Co} / \mathrm{PET}$ has the lowest potential with a 0.53 FGI value. After Fire-off finishing treatment, FGI values of fabrics decreased (PET: from 0.93 to 0.67, cotton: from 0.76 to $0.66, \mathrm{Co} / \mathrm{PET}$ : from 0.53 to 0.30 ), thus fabrics became safer.

\section{CONCLUSION}

In this study, a comparative assessment of MCC and TGA characterization techniques on the thermal and fire behavior of cotton, PET and Co/PET blends treated with FR agentFire-off- has been presented. The use of these techniques, TGA and MCC, allowed for the creation of small batch of materials and corresponding formulation as compared to the kilogram sample needed for cone calorimeter testing.
Results revealed that both TGA and MCC test methods provide very close data related to degradation behaviors and mass loss rates of textile fabrics, which was confirmed by cotton, PET and Co/PET blended fabrics in this study. TGA results indicate that FR treatment with Fire-off leads the decrease of degradation time of the treated samples than the untreated ones. This is in agreement with the MCC results, which also show the FR properties are improving with the decreasing HRR values.

As known very well, TGA data reflect the characteristics of thermal decomposition and degradation of all types of materials with changing temperatures, but not combustion. However, MCC technique covers TGA providing additional combustion characteristics such as HRC, THR and pHRR, which are the most prominent parameters related to fire hazard of textile materials in a shorter heating cycle and time. In addition, MCC data also enable to calculate the FGI of fabric samples. Therefore, the results of this study highlighted that thermal characteristics and combustion behaviors of FR textile materials can be assessed by MCC alone, without performing TGA. TGA could be used for more detailed mass loss assessment of the textile materials in terms of degradation steps with slow linear heating rate. However, both test technique should be conducted for comprehensive thermal evaluation.

\section{ACKNOWLEDGEMENT}

The work was financially supported by ITU BAP Program for the Doctoral Program of Higher Education (Project no: 39775). We wish to thank Zorlu Mensucat for fabric supply. We extend our appreciation to Prof. Dr. Nevin Çiğdem Gürsoy for laboratory facilities in "İ.T.Ü Universal Textile Design Center" to perform chemical finishing applications and Prof. Dr. Mustafa Üreyen for laboratory facilities to perform Micro Combustion Calorimetry (MCC) Test in "Anadolu University Civil Aviation Research Center".

\section{REFERENCES}

1. A.R. Horrocks. 2011. Flame retardant challenges for textiles and fibres: New chemistry versus innovatory solutions. Polymer Degradation and Stability 96, 377-392. doi:10.1016/j.polymdegradstab.2010.03.036.

2. Q. hua Zhang, J. Gu, G. qiang Chen, T. ling Xing. 2016. Durable flame retardant finish for silk fabric using boron hybrid silica sol. Applied Surface Science 387, 446-453. doi:10.1016/j.apsusc.2016.06.119.

3. M. Przybylak, H. Maciejewski, A. Dutkiewicz, D. Wesołek, M. Władyka-Przybylak. 2016. Multifunctional, strongly hydrophobic and flame-retarded cotton fabrics modified with flame retardant agents and silicon compounds. Polymer Degradation Stability 128, 55-64. doi:10.1016/j.polymdegradstab.2016.03.003.

4. I. Šimkovic. 2012. TG/DTG/DTA evaluation of flame retarded cotton fabrics and comparison to cone calorimeter data. Carbohydrate Polymers 90, 976-981. doi:10.1016/j.carbpol.2012.06.030.

5. R.E. Lyon, R. Walters. 2002. A microscale combustion calorimeter (Report No. ADA401490). USA: Defense Technical Information Center.
6. B. Schartel, K.H. Pawlowski, R.E. Lyon. 2007. Pyrolysis combustion flow calorimeter: A tool to assess flame retarded PC/ABS materials? Thermochimica Acta 462, 1-14. doi:10.1016/j.tca.2007.05.021.

7. J. Alongi, J. Tata, F. Carosio, G. Rosace, A. Frache, G. Camino. 2015. A comparative analysis of nanoparticle adsorption as fire-protection approach for fabrics. Polymers (Basel). 7, 47-68. doi:10.3390/polym 7010047.

8. C.Q. Yang, Q. He, R.E. Lyon, Y. Hu. 2010. Investigation of the flammability of different textile fabrics using micro-scale combustion calorimetry. Polymer Degradation and Stability 95, 108-115. doi:10.1016/j.polymdegradstab.2009.11.047.

9. K. Apaydin, A. Laachachi, V. Ball, M. Jimenez, S. Bourbigot, D. Ruch. 2015. Layer-by-layer deposition of a TiO2-filled intumescent coating and its effect on the flame retardancy of polyamide and polyester fabrics. Colloids and Surfaces A: Physicochemical and Engineering Aspects 469, 1-10. doi:10.1016/j.colsurfa.2014.12.021. 
10. L. Chen, L. Song, P. Lv, G. Jie, Q. Tai, W. Xing, Y. Hu. 2011. A new intumescent flame retardant containing phosphorus and nitrogen: Preparation, thermal properties and application to UV curable coating. Progress in Organic Coatings 70, 59-66. doi:10.1016/j.porgcoat. 2010.10.002

11. M. Zarrelli, A. Pullara, M. Codda, E. Amendola, A. Borriello, P. Fermi. 2012, June. Fireproof silicone sealants for shipbuilding. ECCM15 - 15th European Conference On Composite Materials, Venice, Italy.

12. H. Lu, C.A. Wilkie, M. Ding, L. Song. 2011. Flammability performance of poly(vinyl alcohol) nanocomposites with zirconium phosphate and layered silicates. Polymer Degradation and Stability 96 , 1219-1224. doi:10.1016/j.polymdegradstab.2011.04.014.

13. H. Behniafar, S. Haghighat. 2008. Thermally stable and organosoluble binaphthylene-based poly(urea-ether-imide)s: one-pot preparation and characterization. Polymers for Advanced Technologies 19(8), 10401047. doi:10.1002/pat.1072.

14. H. Lu, C.A. Wilkie. 2010. Study on intumescent flame retarded polystyrene composites with improved flame retardancy. Polymer Degradation and Stability 95, 2388-2395. doi:10.1016/ j.polymdegradstab. 2010.08.022.

15. H. Lu, C.A. Wilkie. 2010. Synergistic effect of carbon nanotubes and decabromodiphenyl oxide/Sb2O3 in improving the flame retardancy of polystyrene. Polymer Degradation Stability 95, 564-571. doi:10.1016/j.polymdegradstab.2009.12.011.

16. F. Fang, X. Zhang, Y. Meng, X. Ding, C. Bao, S. Li, H. Zhang, X. Tian. 2016. Boron-containing intumescent multilayer nanocoating for extinguishing flame on cotton fabric. Cellulose 23, 2161-2172. doi:10.1007/s10570-016-0928-8.

17. X.W. Cheng, J.P. Guan, R.C. Tang, K.Q. Liu. 2016. Phytic acid as a bio-based phosphorus flame retardant for poly(lactic acid) nonwoven fabric. Journal of Cleaner Production 124, 114-119. doi:10.1016/j.jclepro.2016.02.113.

18. F. Fang, X. Chen, X. Zhang, C. Cheng, D. Xiao, Y. Meng, X. Ding, H Zhang, X. Tian. 2016. Environmentally friendly assembly multilayer coating for flame retardant and antimicrobial cotton fabric. Progress in Organic Coatings 90, 258-266. doi:10.1016/j.porgcoat.2015.09.025.

19. Q. Zhang, W. Zhang, J. Huang, Y. Lai, T. Xing, G. Chen, W. Jin, H. Liu, B. Sun. 2015. Flame retardance and thermal stability of wool fabric treated by boron containing silica sols. Materials \&Design 85, 796-799. doi:10.1016/j.matdes.2015.07.163.

20. C.Q. Yang, Q. He. 2011. Applications of micro-scale combustion calorimetry to the studies of cotton and nylon fabrics treated with organophosphorus flame retardants. Journal of Analytical and Applied Pyrolysis 91, 125-133. doi:10.1016/j.jaap.2011.01.012.

21. Q. hua Zhang, G. qiang Chen, T. ling Xing. 2017. Silk flame retardant finish by ternary silica sol containing boron and nitrogen. Applied Surface Science 421, 52-60. doi:10.1016/j.apsusc.2017.01.283.

22. J. Alongi, J. Milnes, G. Malucelli, S. Bourbigot, B. Kandola. 2014 Thermal degradation of DNA-treated cotton fabrics under different heating conditions. Journal of Analytical and Applied Pyrolysis 108, 212-221. doi:10.1016/j.jaap.2014.04.014.

23. Q. Chen, C.Q. Yang, T. Zhao. 2014. Heat release properties and flammability of the nylon/cotton blend fabric treated with a crosslinkable organophosphorus flame retardant system. Journal of Analytical and Applied Pyrolysis 110, 205-212. doi:10.1016/j.jaap. 2014.08.021.
24. C.Q. Yang, Q. He. 2011. Applications of micro-scale combustion calorimetry to the studies of cotton and nylon fabrics treated with organophosphorus flame retardants. Journal of Analytical and Applied Pyrolysis 91, 125-133.

25. X.W. Cheng, J.P. Guan, R.C. Tang, K.Q. Liu. 2016. Improvement of flame retardancy of poly(lactic acid) nonwoven fabric with a phosphorus- containing flame retardant. Journal of Industrial Textiles 46, 914-928. doi:10.1177/1528083715606105.

26. Z. Yang, H. Ai-Huayi, J.Y. Liu, X. Zhao. 2016. Study of Fire Hazard of Flooring Materials on Data of Cone Calorimeter, Procedia Engineering 135, 584-587. doi:10.1016/j.proeng.2016.01.113.

27. S. Gaan, L. Mauclaire, P. Rupper, V. Salimova, T.-T. Tran, M. Heuberger. 2011. Thermal degradation of cellulose acetate in presence of bis-phosphoramidates. Journal of Analytical and Applied Pyrolysis 90, 33-41.

28. C. Hirsch, B. Striegl, S. Mathes, C. Adlhart, M. Edelmann, E. Bono, S. Gaan, K.A. Salmeia, L. Hoelting, A. Krebs, J. Nyffeler, R. Pape, A. Bürkle, M. Leist, P. Wick, S. Schildknecht. 2017. Multiparameter toxicity assessment of novel DOPO-derived organophosphorus flame retardants. Archives of Toxicology 91, 407-425. doi:10.1007/s00204016-1680-4.

29. S. Nazare, B. Kandola, A.R. Horrocks. 2002. Use of cone calorimetry to quantify the burning hazard of apparel fabrics. Fire and Materials 26, 191-199.

30. A.R. Horrocks. 2013. Textile flammability research since 1980 Personal challenges and partial solutions. Polymer Degradation and Stability 98, 2813-2824. doi:10.1016/j.polymdegradstab.2013.10.004.

31. K.A. Salmeia, S. Gaan, G. Malucelli. 2016. Recent advances for flame retardancy of textiles based on phosphorus chemistry. Polymers 8, 319 .

32. M. Liu, S. Huang, G. Zhang, F. Zhang. 2019. Synthesis of P-N - Si synergistic flame retardant based on a cyclodiphosphazane derivative for use on cotton fabric. Cellulose 26, 7553-7567. doi:10.1007/s10570019-02608-5.

33. F. Xu, L. Zhong, C. Zhang, P. Wang, F. Zhang, G. Zhang. 2019. Novel High-Efficiency Casein-Based P-N-Containing Flame Retardants with Multiple Reactive Groups for Cotton Fabrics. ACS Sustainable Chemistry\& Engineering 7, 13999-14008. doi:10.1021/acssuschemeng. $9 \mathrm{~b} 02474$.

34. R. Atakan, A. Bical, E. Celebi, G. Ozcan, N. Soydan, A.S. Sarac. 2018. Development of a flame retardant chemical for finishing of cotton, polyester, and CO/PET blends. Journal of Industrial Textiles 49 (2), 1121. doi:10.1177/1528083718772303.

35. R. Atakan and G. Ozcan. 2018. Mechanical Assessments of Fire-off on CO/PET Fabrics. IOP Conference Series: Material Science and Engineering 460,012052. doi:10.1088/1757-899X/460/1/012052.

36. S. Gaan, G. Sun, K. Hutches, M.H. Engelhard. 2008. Effect of nitrogen additives on flame retardant action of tributyl phosphate: Phosphorusnitrogen synergism. Polymer Degradation and Stability 93, 99-108. doi:10.1016/j.polymdegradstab.2007.10.013.

37. T.M. Nguyen, S.C. Chang, B. Condon. 2014. The comparison of differences in flammability and thermal degradation between cotton fabrics treated with phosphoramidate derivatives. Polymers for Advanced Technologies 25, 665-672. doi:10.1002/pat.3268.

38. A.R. Horrocks, D. Price. 2001. Fire retardant materials. UK: Woodhead Publishing. 